\title{
Intellectual property rights in Brazilian floriculture: innovations for the growth and development of the market ${ }^{(1)}$
}

\author{
ANTONIO HÉLIO JUNQUEIRA ${ }^{(2)}$ and MARCIA DA SILVA PEETZ(2)*
}

\begin{abstract}
One of the most important demands imposed by the consumer market on the Brazilian Productive Chain of Flowers and Ornamental Plants is the constant launching of innovations in cultivated species and varieties. Such innovations include the constant introduction of flowers and plants not yet grown and commercialized, both native and adapted exotic species, as well as transformations and changes in size, shape, coloring and conduction patterns and presentation of these goods to the market. Brazil does not have a relevant breeding and cultivation industry. In this sense, it is highly dependent on imports of genetic material developed by countries such as the Netherlands, Germany, Japan, the United States of America, Thailand, among others. Recent developments in the sectoral policy to protect the rights of genetic developers, in the development of internationally adequate legislation and in the control of the use and trade of cultivars, has allowed Brazil greater access to new genetic materials of high quality and in line with contemporary international trends in the consumption. This article aims to discuss the state of the art of protection of cultivars in Brazil, pointing to the advances that the legislation and the inspection have allowed in relation to the introduction of genetic innovations, evaluating the impact of these measures on the growth and development of the market of consumption of flowers and ornamental plants in the country.
\end{abstract}

Keywords: innovation, intellectual property, cultivars, market, consumption.

\section{RESUMO}

Direitos de propriedade intelectual na floricultura brasileira: inovações para o crescimento e o desenvolvimento do mercado

Uma das mais importantes demandas impostas pelo mercado consumidor à Cadeia Produtiva de Flores e Plantas Ornamentais do Brasil é o constante lançamento de novidades e inovações nas espécies e variedades cultivadas. Tais inovações incluem a introdução constante de flores e plantas ainda não cultivadas e comercializadas, tanto de espécies nativas, quanto de exóticas adaptadas, e, também, transformações e mudanças nos padrões de tamanho, formato, coloração e formas de condução e apresentação dessas mercadorias ao mercado. O Brasil não detém relevante indústria de criação e lançamento de cultivares, sendo, nesse sentido, altamente dependente da importação de material genético desenvolvido por países como Holanda, Alemanha, Japão, Estados Unidos da América, Tailândia, entre outros. A evolução recente na política setorial de proteção dos direitos dos desenvolvedores genéticos, no desenvolvimento de legislação internacionalmente adequada e na fiscalização do uso e comércio de cultivares vem permitindo maior acesso do Brasil a novos materiais genéticos de alta qualidade e alinhados às tendências internacionais contemporâneas do mercado de consumo. O presente artigo visa a discutir o estado da arte da proteção de cultivares no Brasil, apontando para os avanços que a legislação e a fiscalização vêm permitindo em relação à introdução de inovações genéticas, avaliando o impacto dessas medidas sobre o crescimento e o desenvolvimento do mercado de consumo de flores e plantas ornamentais no país.

Palavras-chave: inovação, propriedade intelectual, cultivares, mercado, consumo.

\section{INTRODUCTION}

In Brazil, the Law on Protection of Cultivars - LPC (Law No. 9,456) was sanctioned on April 25, 1997, followed by Decree No. 2,366, of November 5 of that year, which together constituted the National System of Protection of Cultivars. As a result of this, the National Register of Cultivars (NRC) was created within the scope of the Ministry of Agriculture, Livestock and Supply, in order to control the compulsory registration of plants grown in economic farms. Under current legislation, a plant can only be protected if it has its biological descriptors published in the Official Gazette of the Union, by the National Service of Protection of Cultivars. It should be noted that the first biological descriptors of ornamental cultivars were only published in Brazil in the year of 2002 and referred to roses.

The Brazilian sectorial legislation was created under the Agreement on Trade Related Aspects of Intellectual Property Rights, established during the Uruguay Round of Multilateral Trade Negotiations of the General Agreement on Tariffs and Trade (GATT), later transformed into World Trade Organization (WTO). 
Since April 1999, the country has joined the intergovernmental organization Union pour la Protéccion des Obtenciones Vegetales UPOV, based in Switzerland, dedicated to the protection of new varieties developed through Plant Breeder's Rights (PBR). Thus, the intellectual rights of the development of new cultivars in the country were protected for a period of 15 years, with guarantees of the corresponding royalties (BROEK et al., 2006).

This article begins by presenting the main characteristics of the Brazilian market of flowers and ornamental plants, with regard to cultivated species, highlighting the importance of the permanent introduction of commercial novelties. Then, it explores the results of the implementation of the Law of Protection of Cultivars in the different sectors of Brazilian agribusiness, relating official data on the evolution of the number of cultivars registered and effectively protected, year by year. Sequentially, it points to the species that had the greatest amount of records and obtaining protection certificates, highlighting their commercial, public or private. Finally, it points to final and general considerations about the impacts of the Law of
Protection of Cultivars in Brazil, suggesting some ways for new studies in the sector.

Brazilian consumption of flowers and ornamental plants - which reached R\$ 6.5 billion in 2016, with projections of annual growth of between $4 \%$ and $6 \%$ in the coming years - is still considered, for the most part, typical of emerging markets, for which predominate: i) low per capita consumption; ii) low percentage of buyers; iii) traditional assortment; iv) consumption concentrated in few special ocasions (Mother Day, Women's Day; weddings etc. (JUNQUEIRA and PEETZ, 2017). Only for certain portions of the population and market niches can there be a more diversified demand for the number of species and different occasions of purchase and consumption.

Due to this reason and also to the high concentration of production, trade and national distribution by the State of São Paulo, the Brazilian consumption of flowers and ornamental plants is concentrated in a very small number of species, both for flowers and cut foliage, and for potted flowes and plants and ornamental plants for gardening and landscaping (Table 1).

Table 1. BRAZIL. Main flowers and ornamental plants produced and consumed in the domestic market.

\begin{tabular}{|c|c|c|c|}
\hline Cut flowers & Potted flowers & Cut foliages & Potted plants \\
\hline $\begin{array}{c}\text { Rose } \\
(\text { Rosa } \mathrm{sp} .)\end{array}$ & $\begin{array}{c}\text { Orchids } \\
\text { (Cattleya sp., Dendrobium sp., } \\
\text { Phalaenopsis sp. and others) }\end{array}$ & $\begin{array}{c}\text { Leather leaf fern } \\
\text { (Ruhmora adiantiformis) }\end{array}$ & $\begin{array}{c}\text { Dieffenbachia } \\
\text { (Dieffenbachia } \mathrm{sp} .)\end{array}$ \\
\hline $\begin{array}{c}\text { Chrysantemum } \\
\text { (Dendranthema grandiflorum) }\end{array}$ & $\begin{array}{c}\text { Kalanchoe } \\
\text { (Kalanchoe blossfeldiana) }\end{array}$ & $\begin{array}{c}\text { Ferns } \\
\text { (Nephrolepsis sp. and others) }\end{array}$ & $\begin{array}{c}\text { Epipremnum } \\
\text { (Epipremnum pinnatum) }\end{array}$ \\
\hline $\begin{array}{c}\text { Lisiantus } \\
\text { (Lisianthus sp.) }\end{array}$ & $\begin{array}{c}\text { Anthurium } \\
\text { (Anthurium andreanum) }\end{array}$ & $\begin{array}{c}\text { Palms leaves } \\
\text { (Areca bambu, Livistonia and } \\
\text { others) }\end{array}$ & $\begin{array}{c}\text { Ferns } \\
\text { (Nephrolepsis sp. and others) }\end{array}$ \\
\hline $\begin{array}{c}\text { Lily } \\
\text { (Lilium sp.) }\end{array}$ & $\begin{array}{c}\text { Chrysantemum } \\
\text { (Dendranthema grandiflorum) }\end{array}$ & $\begin{array}{l}\text { Anthurium leaves } \\
\text { (Anturium sp.) }\end{array}$ & $\begin{array}{l}\text { Suculentas } \\
\text { (various) }\end{array}$ \\
\hline $\begin{array}{c}\text { Gerbera } \\
(\text { Gerbera jamesonii) }\end{array}$ & $\begin{array}{c}\text { Lily } \\
\text { (Lilium sp.) }\end{array}$ & $\begin{array}{c}\text { Monstera } \\
(\text { Monstera deliciosa) }\end{array}$ & $\begin{array}{c}\text { Bromeliads } \\
\text { (Vriesea } \text { sp.; Neoregelia } \text { sp. } \\
\text { and others) }\end{array}$ \\
\hline $\begin{array}{c}\text { Orchids } \\
\text { (Phalaenopsis sp, Oncidium } \\
\text { sp. and others) }\end{array}$ & $\begin{array}{c}\text { African violet } \\
\text { (Saintpaulia ionantha) }\end{array}$ & $\begin{array}{c}\text { Phormium } \\
\text { (Phormium sp.) }\end{array}$ & $\begin{array}{c}\text { Ficus } \\
\text { (Ficus benjamina and others) }\end{array}$ \\
\hline $\begin{array}{c}\text { Alstroemeria } \\
\text { (Alstroemeria } \text { sp.) }\end{array}$ & $\begin{array}{c}\text { Gerbera } \\
(\text { Gerbera jamesonii) }\end{array}$ & $\begin{array}{c}\text { Murta } \\
\text { (Murraya } \mathrm{sp})\end{array}$ & $\begin{array}{c}\text { Schefflera (Schefflera } \\
\text { arboricola) }\end{array}$ \\
\hline $\begin{array}{c}\text { Solidago } \\
\text { (Solidago sp.) }\end{array}$ & $\begin{array}{l}\text { Rododendrum } \\
\text { (Rododendrum sp.) }\end{array}$ & $\begin{array}{c}\text { Ruscus } \\
\text { (Ruscus aculeatus) }\end{array}$ & $\begin{array}{c}\text { Syngonium (Syngonium } \\
\text { angustatum ) }\end{array}$ \\
\hline $\begin{array}{c}\text { Gladiolus } \\
\text { (Gladiolus hortulanus) }\end{array}$ & $\begin{array}{c}\text { Begonia } \\
\text { (Begonia } \text { spp.) }\end{array}$ & $\begin{array}{c}\text { Juncus } \\
\text { (Equisetum giganteum) }\end{array}$ & $\begin{array}{l}\text { Chamaecyparis } \\
\text { (Chamaecyparis sp.) }\end{array}$ \\
\hline $\begin{array}{c}\text { Gipsofila } \\
\text { (Gypsophila } \mathrm{sp} .)\end{array}$ & $\begin{array}{c}\text { Hippeastrum } \\
\text { (Hippeastrum } s p \text { ) }\end{array}$ & $\begin{array}{c}\text { Asparagus } \\
\text { (Asparagus } \mathrm{sp})\end{array}$ & $\begin{array}{l}\text { Philodendron } \\
\text { (Philodendron) }\end{array}$ \\
\hline
\end{tabular}

(Sources: adapted from Junqueira and Peetz (2008, 2017); Paiva et al. (2016)).

In this sense, the maintenance of market dynamics is highly dependent on innovation and varietal renewal, especially of the most consumed species (SÁ and SAES, 2015), such as: chrysanthemums, roses, alstroemeria, anthurium, kalanchoes, among a few others.
Annually, dozens of new cultivars are introduced in the consumer market, mainly seeking the aggregation of new colors, formats, sizes and modes of use. From the producers' point of view the varietal innovation also aims to obtain (JUNQUEIRA and PEETZ, 2016): i) higher rates of 
resistance to pests and tropical diseases; ii) better adaptation to Brazilian climatic conditions; iii) longer harvesting time (greater or lesser precocity, depending on the case); iv) greater post-harvest durability; v) higher degree of homogeneity, aiming at the commercial standardization of products and vi) higher productivity.

Brazil does not have an economically relevant genetic development industry for flowers and ornamental plants, being highly dependent on imports of basic material from international breeders, mainly Dutch. The highly endogenous economic and cultural relations between Brazilian producers particularly concentrated in the region of Holambra (SP) - and Dutch companies of genetic development have contributed, among other factors, to discourage a greater participation of national breeders and researchers in the segment. There are also important factors for the non-expansion of this industry in Brazil: i) low public investments in plant genetics with ornamental purposes; ii) the small number of research institutions and researchers involved; iii) the long time necessary to obtain products ready for commercial launch, as opposed to shorter life cycles of the cultivars on the market (JUNQUEIRA and PEETZ, 2016).

In the internal production of new varieties and cultivars of commercial ornamental interest, are relevant the works of the Agronomic Institute of Campinas (IAC), of the Secretariat of Agriculture and Supply of the Government of the State of São Paulo and Empresa Brasileira de Pesquisa Agropecuária - Embrapa (Brazilian Agricultural Research Corporation ). In the case of the first institution, among the main species selected and improved, the following stand out in particular: Anthurium andreanum, Hippeastrum sp., Hemerocallis sp. and Gladiolus sp.

As for Embrapa, in general, in the area of research and genetic development of flowers and ornamental plants, programs have been distinguished by the ornamental development of products from other segments of commercial interest, such as fruit growing (pineapple and ornamental passion fruit) and production of oleaginous plants (ornamental sunflower).

In the private segment, the genetic research and development of varieties and cultivars is greatly reduced. Among the few highlights are the improvement and propagation of Zantedeschia (ProClone, from Holambra) and ornamental grasses, Zoysia japonica Steud (Itogras). In the case of the latter, obtaining the registration of protection of cultivar in Brazil allowed the commercialization of the product in the USA (Florida, Texas, South Carolina, Arkansas and Alabama), becoming the first Brazilian ornamental cultivar to receive royalties abroad.

The ornamental varietal supply of the Brazilian domestic market is essentially guaranteed by imports of seeds and seedlings of genetic material developed abroad, especially in the Netherlands, Japan, Germany, USA and Thailand, among other countries. Much of the imported material is marketed directly to producers. It is only in recent years that the practice of producing seedlings has begun to be generalized by accredited nurseries from seed germination, which are then offered to flower growers to obtain the final products.
According to the website of the Brazilian Association of Seed, Seedlings and Young Plants Trade - Abcsem (http:// www.abcsem.com.br/), in July 2017, 26 companies were operating in Brazil in the seed, seedlings and young plants segment of flowers and ornamentals, strongly concentrated in the Southeast and South regions of the country.

For many years now, these companies that produce, import or propagate seed, seedlings and young plants have agreed to use the opportunity of holding the main fairs and sector events to focus the launch of news for the following climatic seasons. They are: the National Meeting of Florists and Garden Fair (July) and Expoflora (September), both held annually in the city of Holambra (SP).

Prior to the implementation of crop protection legislation, Brazil did not effectively benefit from cuttingedge launches for global floriculture, remaining oblivious to new achievements and innovative and attractive consumer opportunities and the full development of the activity, both for the internal and international markets (JUNQUEIRA and PEETZ, 2016, 2017). This article aims to discuss the state of the art of protection of cultivars in Brazil, pointing to the advances that the legislation and the inspection have allowed in relation to the introduction of genetic innovations, evaluating the impact of these measures on the growth and development of the market of consumption of flowers and ornamental plants in the country.

\section{THE FEDERAL REGULATORY SPHERE: REGISTRATION AND PROTECTION OF CULTIVARS IN BRAZIL - DIFFICULTIES AND LIMITATIONS}

In Brazil, to obtain the protection of cultivar, the new plant product is submitted to the test of distinction, homogeneity and stability (DHE), which aims to prove the differentiation of its attributes. In the distinction items, the cultivar must present distinct differences in relation to the others already recognized. As for homogeneity, the criterion is the minimum variation regarding the characteristics of the cultivar when it is produced on a large scale. On the other hand, the attribute of homogeneity refers to the stability of transmission of distinctive features across multiple generations when reproduced on a commercial scale. In order to obtain protection, the cultivar can not be present and has been marketed in the country for over a year or for more than four years abroad (UPOV, 2005).

One of the greatest weaknesses of the LPC, as pointed out by the breeders themselves, is in the device that allows the producer to reserve and plant seeds for his own use (BRASIL, 1997). Originally, such a device was aimed at protecting family-owned food-producing agriculture and traditional varieties. However, when applied indistinctly to the flower and ornamentals sector, it eventually favored the illegal reproduction of protected cultivars. In this sense, it allowed the continuity of the misappropriation of varietal genetic innovations, discouraging the transfer of news to Brazil (VAN ROOIJEN, 2006).

As one way to overcome this limitation, market agents believe that the application of the Law on Seeds and 
Seedlings - approved along with the Law of Protection of Cultivars, but only effectively sanctioned in 2003 - allows to avoid the claim of own use by the floriculturists who can not to verify the origin of the propagating material used for planting (BROEK et al., 2006; SÁ, 2010; SÁ and SAES, 2015).

In general, besides the failures of the legislation, one of the biggest obstacles pointed out by the Brazilian breeders for the growth of the protection of national cultivars has been the high financial cost of the process of obtaining the certificate (SÁ, 2010; SA and SAES, 2015) . In addition, other problems arise from the difficulties and limitations of inspection in the domestic market and the tight time frames between the introduction of the new cultivar and the maximum time allowed for its effective protection, often insufficient to test the receptivity of the cultivar with producers and consumers.

An important part of international breeding companies of the main species of flowers and ornamental plants produced and marketed in Brazil have established branches or representative offices in the main national producing regions. It is observed that the genetic material developed by them is totally produced in international research environments, being only field tested in national territory for performance observation and market acceptance. There is no record of the development, by these companies, of new materials directly in the Brazilian field.

In order to obtain guarantees for the effective appropriation of intellectual property rights for their work, flower and ornamental plant breeders in Brazil establish specific contracts with Brazilian flower growers, which include a mandatory clause for the non-propagation of seeds or vegetative propagules under their own use (SÁ, 2010; SÁ and SAES, 2015). It is observed that from the point of view of Transaction Cost Economics (WILLIANSON, 1994), such measures entail significant costs, arising not only from the detailed elaboration of the contracts but also from those due to the monitoring and control they require.

In Brazil, according to data provided by the Ministry of Agriculture, Livestock and Food Supply, until mid-July 2017, there were 35,621 cultivars of agricultural interest registered, of which only 2,536 were protected $(7.1 \%)$. Of the cultivars registered, 14,233 were of flowers and ornamental plants, representing $39.96 \%$ of the total registrations (see Figure 1) (CARPI, 2017). This information confirms, also for Brazil, the world tendency of the flower and ornamental plants sector to surpass the others in numbers of cultivars registers.

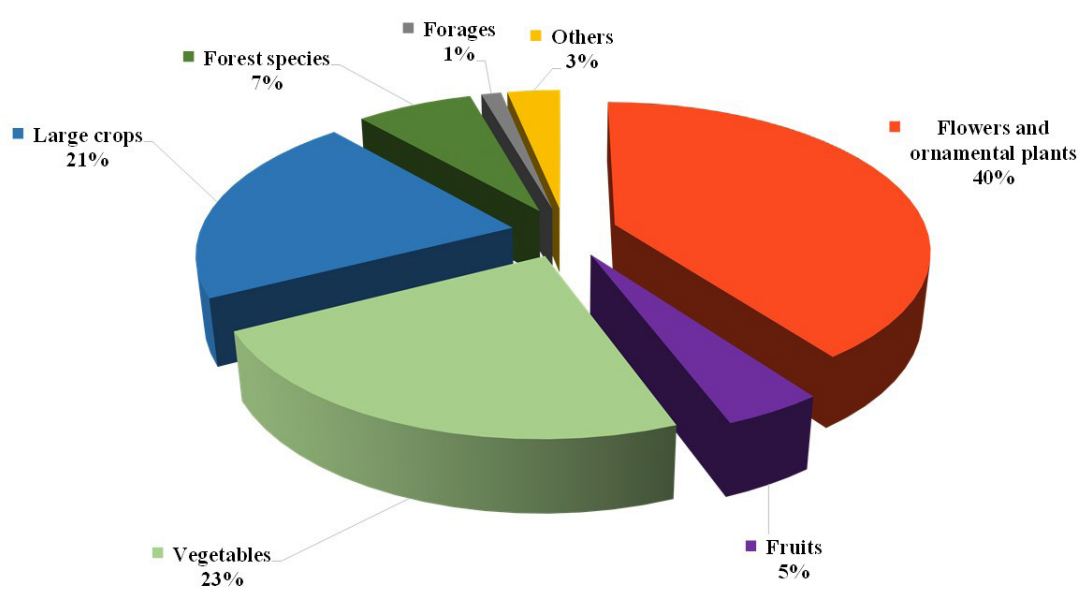

Figure 1. Brazil. Protected cultivars by groups, until July 2017. Source: Brazilian Ministry of Agriculture, Livestock and Food Supply, july 2017 (CARPI, 2017).

Among the registered ornamental cultivars, the most significant species are currently: orchids (2,345), chrisantemuns (1,072), pansys (952), gerberas (690), tagetes and carnations (672), petunias (617), impatiens (599) and lisianthus (489), among others species (CARPI, 2017) (Table 2). 
Table 2. Brazil. Registred cultivars of flowers and ornamental plants, by species, until July 2017.

\begin{tabular}{|c|c|}
\hline Common name & Number of cultivars registered \\
\hline Orchid & 2,345 \\
\hline Chrysanthemum & 1,072 \\
\hline Pansy & 952 \\
\hline Gerbera & 690 \\
\hline Carnation/Tagetes & 672 \\
\hline Petunia & 617 \\
\hline Impatiens & 599 \\
\hline Lisianthus & 489 \\
\hline Lily & 375 \\
\hline Cyclamen & 362 \\
\hline Snapdragon & 339 \\
\hline Begonia & 333 \\
\hline Anthurium & 249 \\
\hline Rose & 200 \\
\hline Others & 4,939 \\
\hline TOTAL & $\mathbf{1 4 , 2 3 3}$ \\
\hline
\end{tabular}

(Source: Brazilian Ministry of Agriculture, Livestock and Food Supply, July 2017 (CARPI, 2017)).

Over the years, one can observe a great variation in the annual number of registrations granted, and the period of greatest concentration occurred between the years 2000 to
2004, that is, in the first five years after the entry into force of the sectoral legislation .

Table 3. Brazil. Evolution of the number of registered cultivars of flowers and ornamental plants, 1999-2017.

\begin{tabular}{|c|c|}
\hline Year & Number of cultivars registered \\
\hline 1999 & 68 \\
\hline 2000 & 3,668 \\
\hline 2001 & 900 \\
\hline 2002 & 1,941 \\
\hline 2003 & 2,698 \\
\hline 2004 & 1,355 \\
\hline 2005 & 308 \\
\hline 2006 & 165 \\
\hline 2007 & 154 \\
\hline 2008 & 367 \\
\hline 2009 & 128 \\
\hline 2010 & 269 \\
\hline 2011 & 219 \\
\hline 2012 & 153 \\
\hline 2013 & 507 \\
\hline 2014 & 330 \\
\hline 2015 & 462 \\
\hline 2016 & 303 \\
\hline $2017($ July, 17) & 238 \\
\hline TOTAL & 14,233 \\
\hline & \\
\hline & \\
\hline
\end{tabular}

(Source: Brazilian Ministry of Agriculture, Livestock and Food Supply, July 2017 (CARPI, 2017)). 
Among all the cultivars of agricultural interest currently protected in Brazil, 392 refer to cultivars of flowers and ornamental plants (15.5\%) (BRAZIL, 2017). It is observed that the species with the highest number of protected cultivars coincide with the main species produced and marketed in the country.

Among the main protected cultivars of cut flowers are: chrysanthemum (26.5\% of total protected), roses (15.6\%), alstroemeria $(13.3 \%)$, gerbera $(2.6 \%)$ and gypsophila
$2.0 \%)$. Pot flowers includes: anthurium (9.9\%), kananchoes $(7.9 \%)$, begonia $(4.8 \%)$, phalaenopsis $(4.6 \%)$, African violets $(3.6 \%)$, spathiphyllum $0.8 \%$ ), oncidium $(0.8 \%)$, poinsettia $(0.8 \%)$, celosia $(0.5 \%)$, codiaeum $(0.5 \%)$, amaryllis $(0.3 \%)$ and zantedeschia $3 \%)$. Finally, among the ornamental plants to landscaping and gardening stand out: impatiens new guinea (3.6\%), hibiscus $(0.8 \%)$, ornamental passion fruit $(0,3 \%)$, and cultivars of garden grass $8 \%$ ) (see Table 4).

Table 4. Brazil. Protected cultivars of flowers and ornamental plants, by species, until July 2017.

\begin{tabular}{|c|c|c|}
\hline Common name & Scientific name & Number of protected cultivars \\
\hline Chrysanthemum & $\begin{array}{l}\text { Chrystantemum } \mathrm{L} \text {. } \\
\text { Chrysantemum } x \text { morifolium Ramat. }\end{array}$ & $\begin{array}{c}95 \\
9\end{array}$ \\
\hline Rose & Rosa L. & 61 \\
\hline Alstroemeria & Alstroemeria (L.) & 52 \\
\hline Anthurium & Anthurium Schott & 39 \\
\hline Kalanchoe & $\begin{array}{c}\text { Kalanchoe Adans. } \\
\text { Kalanchoe blossfeldiana Poelln. }\end{array}$ & $\begin{array}{l}11 \\
20\end{array}$ \\
\hline Phalaenopsis & Phalaenopsis Blume & 18 \\
\hline African violet & Saintpaulia H. Wendl. & 14 \\
\hline Impatiens new guinea & Impatiens $x$ Nova Guine & 14 \\
\hline Begonia & $\begin{array}{c}\text { Begonia elatior } \\
\text { Begona rex and hibrids }\end{array}$ & $\begin{array}{c}14 \\
5\end{array}$ \\
\hline Gerbera & Gerbera L. & 10 \\
\hline Gypsophila & Gypsophila L. & 8 \\
\hline Spathiphyllum & Spathiphyllum Schott. & 3 \\
\hline Hibiscus & Hibiscus rosa-sinensis & 3 \\
\hline Oncidium & Oncidium Sw. & 3 \\
\hline Poinséttia & Euphorbia pulcherrima Willd. Ex Klotzch & 3 \\
\hline Celosia & Celosia L. & 2 \\
\hline Codiaeum & Codiaeum variegatum (L.) A. Juss & 2 \\
\hline Emerald grass & Zoysia japonica Steud & 2 \\
\hline Bermuda grass & $\begin{array}{l}\text { Cynodon dactylon (L.) Pers. x Cynodon } \\
\text { transvaalensis Burtt Davy }\end{array}$ & 1 \\
\hline Amaryllis & Hippeastrum Herb. & 1 \\
\hline Ornamental passion fruit & Passiflora L. & 1 \\
\hline Zantedeschia & Zantedeschia Sprens. & 1 \\
\hline TOTAL & & 392 \\
\hline
\end{tabular}

Source: Own elaboration, based on data from the Brazilian Ministry of Agriculture, Livestock and Food Supply, July 2017

It should be noted, however, that protected cultivars do not always coincide exactly with those cultivated by producers. In fact, as Sá (2010) has shown, a relevant part of the roses, gerberas and alstroemerias protected in Brazil are not even being produced and marketed by flower growers near the main wholesaler centers. This distortion stems from the Law's own limitations, which impose a very small time interval between the commercial introduction of the cultivar in Brazil and the legal term for its protection. In this way, many developers end up opting to apply for the protection of the cultivar even before the completion of the adaptation and commercial acceptance testing processes in the new product. On the other hand, sometimes breeders become disinterested in the commercial exploitation of the new cultivar, declining from the final realization of the officially granted protection (SÁ, 2010).

In Brazil, there is a strong concentration of protected cultivars in species of commercial vegetative propagation $(91.1 \%)$, in relation to those propagated mainly by seeds $(8.9 \%)$. 
The main species of cut flowers cultivated in Brazil today are: roses $(30 \%)$, chrysanthemums $(15 \%)$, lisianthus $(12 \%)$, lily $(7 \%)$ and gerbera $(6 \%)$. As for flowers and potted ornamental plants, the main species are in descending order of relative importance: orchids (14\%), lily $(7.5 \%)$, chrysanthemum (7\%), kalanchoe (6.4\%), African violet (65) and bromeliad (6\%) (JUNQUEIRA and PEETZ, 2017).

\section{MAIN CHARACTERISTICS AND INNOVATIONS INTRODUCED IN THE BRAZILIAN ORNAMENTAL VARIETAL MARKET}

\section{Roses}

Rose is the main ornamental specie cultivated in Brazil, accounting for about $30 \%$ of the cut flowers market. Predominantly a preference for red flowers and large buttons, especially on the main occasions of shopping for gifts such as Mother's Day, International Women's Day and Brazilian Valentine's Day (June 12). Flowers in white and pink colorations are preferred for wedding ornaments and 15-year-old parties. The other colorations and mixtures have greater penetration along the more sophisticated markets of parties and receptions.

It is important to consider that 61 cultivars are protected and 200 are registered. In the last years, the introduction of cultivars with stems without thorns and of great size of buttons has been valued. Other focuses of interest have been the double coloration of petals, the fragrant flowers, the baby roses and the climbing species.

In Brazil, the first legal proceeding due to non-payment of royalties, as a result of the approval of the Law of Protection of Cultivars occurred in 2009 and had as main protagonist the pink cultivar Versilia Pink, developed in 2002, by Nirp International, based in Cuers, in the South of France and that has been protected in the country since 2006 (CRUZ, 2017). On the occasion of the approval of the Law of Protection of Cultivars in Brazil, two cultivars developed by Nirp - Ambiance and Versilia - represented more than $50 \%$ of the Brazilian market of these flowers (SÁ, 2010). However, by the rules put in place, such cultivars could no longer be protected, since they had been present in Brazilian production and trade for more than a year at the time.

In contracts for the production of protected roses, the amount stipulated for the payment of royalties per plant varies between US\$ 0.90 and US\$ 1.10. The shelf life considered for the plants is about five years (SÁ, 2010).

Currently, the production of rose stems is strongly concentrated in the states of São Paulo (63\%), Minas Gerais (15\%), Ceará (12\%) and Rio Grande do Sul (4.5\%). Other production poles account for only $5,5 \%$.

\section{Chrysantemum}

Chrysanthemum is today one of the most cultivated flowers in the world. It is certainly one of the oldest ornamental plants in the history of mankind. In China, these flowers were cultivated more than 2,000 years ago, and were then scattered, initially to Japan and then to all of Europe, from France in the mid-eighteenth century.
The flower grown today is the result of a series of complex crosses carried out over many years from primitive cultivars, mostly from China. With the development and diversification of markets and the support of modern genetic research, the genus Chrysanthemum has generated a huge range of varieties and cultivars, capable of meeting the most demanding consumer expectations in the world

This great diversity allowed the chrysanthemum to become a plant adapted to the most diverse ornamental uses, standing out among the most sought after in the market of cut flowers, as well as in potted plants and even as a garden plant. It is common to classify the chrysanthemum according to the shape of its inflorescences, which can be of the simple types (like the daisy); anemones (cat's eyes), recurved, pompoms, decorative, globose, among others.

At present, market seeks to diversify, to the maximum, the offer of this product, in a consumption always eager for novelties, appealing not only to the infinite possibilities of combination of formats and colors, but also in the aspects related to the conduction of the plant. Thus, it is possible to obtain both standard flowers (when all flower buds are removed, allowing a single inflorescence per stem to develop), and spray-like formations (when the terminal inflorescence is eliminated, allowing the lateral harmoniously develop). Miniature chrysanthemums for potting were also one of the recent innovations that most captivated the consumer and allowed notable expansion into their market. In Brazil, 1,072 species and cultivars of the group are registered, of which only 104 have protection records.

Aiming at overcoming the national limitations of flower consumption, much associated with funeral ceremonies, new launches have been fundamental for market reinvigoration, like the cultivar "Anastasia", introduced worldwide by the Dutch Deliflor in the market in 2001 and in Brazil in December of 2009, already under protection. The unscented species with large flowers and long stems is offered in the colors: white, cream, yellow, pink, gold bronze, dark bronze and green.

\section{Anthurium}

In Brazil, anthurium cultivars are commercially exploited mainly in the State of São Paulo, with emphasis on Atibaia, Holambra and Ribeira Valley region. In recent years, its dispersion has also been observed in the northeastern region of the country, with emphasis on Pernambuco, Bahia, Ceará and Alagoas. For the market, the anthuriums are divided into four main groups:

I) Cultivars of Anthurium andraeanum Lindl. Specially selected for the cut flower segment, for which the size, size, cerosity, brightness and color of the spatula and spatum, the height of the stems and the uniformity of the production are important. The group's primary colors are: white, pink, red, orange-red, and green. Modern genetic technology has favored innovation in the production of more intense coloring cultivars than the traditional ones, sometimes bicolours and also in exotic colorations such as pistachio green and dark brown. In Brazil, there are 235 cultivars registered in this group. Almost all the 
companies that maintain these cultivars are of Dutch origin or descent, established in the region of Holambra (SP). The only exception is the Agronomic Institute of Campinas (IAC), a public research company in the State of São Paulo, responsible for the development and maintenance of ten cultivars (IAC -Edibel, IAC-Astral, IAC-Cananéia, IAC-Iguape, IAC - Isla, IAC-Juréia, IAC-Luau, IAC-Neptuno, IAC-Omega and IAC-Rubi). In addition to these cultivars registered in the $\mathrm{RNC}$, the IAC developed and maintains another 12 cultivars, which have been given indigenous names (Aikanã, Apalai, Aruak, Ianomami, Kauê, Kinã, Krahô, Krenak, Parakanã, Terena, Xavante and Zoé) and are reproduced and Made available to national producers through in vitro propagation by laboratories of privately accredited micropropagation companies in the State of São Paulo (ClonAgri in the city of Artur Nogueira) and Ceará (Bioclone in the city of Fortaleza);

II) Interspecific hybrid cultivars between $A$. andreanum and dwarf species: almost entirely directed to the production of potted flowers, since the market requires compact plants. They are small in size, with very thick and intense foliage, thick leaves of dark green color, with small but numerous flowers. The primary colors of the group's flowers are: white, pink, red and lilac lavender.

III)Hybrid cultivars of Anthurium scherzerianum: originally, the cultivars were most intensively used for the production of packed anthuriums. They have small, compact plants and flowers in the basic colorations white, pink and red. Currently, in Brazil, 18 cultivars are registered in the group. The totality of these companies are companies of Dutch origin or descent;

IV)Cultivars for the production of cut foliage and for bottled plants: still little known and used in the consumer market. The native flora of Brazil is rich in attractive species for this segment, which stand out for long postharvest durability. The Germplasm Bank of Embrapa has accesses of $A$. plowmanii, A. raimundii, A. blonplandii and $A$. affine, considered of high ornamental potential.

In Brazil, the most important research program focused on the development of cultivars for the market of anthuriums has been that of the Agronomic Institute of Campinas (IAC), started in the 1970's and obtained its first results with propagation of in vitro seedlings from of the 1980's. The cultivars produced by the institute have been well accepted by producers throughout the country, and have also produced excellent results in exports of cut flowers of the species, especially to European countries. Currently, 249 cultivars are registered in the Ministry of Agriculture, Livestock and Supply, compared to 39 effectively protected.

\section{Gerbera}

Gerbera cultivation began in Brazil in 1979, from producers in the municipality of Holambra (SP), then exclusive representatives of the cultivars of the Dutch company Terra Nigra. Currently, 690 gerbera cultivars are registered in the country, while only ten are effectively protected. The market of this ornamental species is one of the most complex for the registration of cultivars. Among the main reasons is the fact that the annual number of new launches is among the highest among ornamental species and the commercial life cycles of new products have been getting shorter, between two and three years only. The great breakthrough in the world market for gerberas occurred in 1990 with the launch of Gemini mini-gerberas by Terra Nigra. Still today the product represents great success of sales, adding about 75 cultivars. However, striking news is not expected in the coming years. The work of genetic innovation today focuses on obtaining better productive performances, especially with regard to economies of labor and energy.

At the global level, the most consumed gerbera colors are pink (including fuchsia, 40\%), red $(20 \%)$, yellow $(10 \%)$, white $(10 \%)$, orange $(10 \%)$ and others $(10 \%)$. As for the type of inflorescence, the consumer prefers folded (between 20\% and 40\%), semi-folded (20\% to 40\%) and simple (30\% to $60 \%$ ) flowers. And with respect to the colors of the central part of the inflorescence, the demand is $20 \%$ to $30 \%$ for black-hearted flowers and $70 \%$ to $80 \%$ for green-hearted flowers (INFOAGRO, 2017).

Since the 1980's, a large number of cultivars have been introduced in Brazil - thus, already without legal right to protection - which still have commercial profitability and attraction for consumers. Currently, the national production of bottled gerbera concentrates in the municipalities of Holambra and region (80\%), in addition to Atibaia, Arujá and Ibiúna.

In the production contracts for protected species, the amount charged as royalties represents, on average, $50 \%$ of the value of the seedlings and is already included in them (SÁ, 2010).

\section{Gladiolus}

The Brazilian gladiolus market has suffered, over time, a strong loss of interest from consumers. Considered saturated and vulgarized by the high rate of exploitation throughout the decades of 1950 to 1980 , the consumption of these flowers is no longer attractive, associating progressively only with funeral ceremonies. The recovery movement of this market only occurred later, with the introduction of innovative cultivars in unusual colors such as green ("Green Star") and purple ("Purple Flora"), both protected and only multiplied in Brazil under contracts and payment of royalties. Brazilian consumer preferences fall into the following colors: white $(40 \%)$, red $(25 \%)$, yellow $(12 \%)$, pink $(10 \%)$, coral/cream $(10 \%)$ and purple $(3 \%)$ (TOMBOLATO et al., 2010, 2013).

The national production is concentrated in the State of São Paulo, especially in the municipalities of Holambra and Santo Antonio de Posse. There are also productions in the States of Rio de Janeiro, Pernambuco, Rio Grande do Sul and Bahia. 


\section{Hippeastrum}

The cultivars currently present in the international market originated from hybridizations carried out in Europe, between Brazilian and Peruvian species, still in the 18th century. Since 1982, the Agronomic Institute of Campinas (IAC) has developed a genetic improvement program for flowers of this genus, aiming to obtain cultivars originating from native species and, consequently, better adapted to the Brazilian ecological conditions. The works produced in partnership with the private company André Boersen, from the region of Holambra (SP), initially generated three hybrids of commercial interest, with smaller flowers and orange coloring and long floral stems: IAC Neblina, IAC Jaraguá and IAC Itatiaia. These cultivars are registered in the National Service of Protection of Cultivars (TOMBOLATO et al., 2010; 2013). The main producers are in the States of São Paulo and Ceará.

The Brazilian consumer prefers red and red/orange $(70 \%)$, bicolores of pink and white $(10 \%)$, white $(10 \%)$ and red and white $(10 \%)$ bicolores (TOMBOLATO et al., 2010, 2013). Currently, 66 cultivars are registered.

\section{Alstroemerias}

In Brazil, there are about 40 native alstroemeria species, which can reach up to 1.5 meters in height, producing small tubular flowers of little commercial interest. In order to collect genetic material for national breeding programs, IAC has already organized field expeditions to set up collections of germplasm banks of native species. From this work, resulted the description of 14 new botanical species of natural occurrence in Brazil (TOMBOLATO et al., 2010; 2013).

In the Brazilian market, the predominance of the supply of hybrids originating mainly of crosses of Andean species, developed by Dutch improvers. The Brazilian market prefers pure colors, such as pink ("Chanel"), yellow ("Firenze" and "Shakira") and red ("Fire"). The bicolor alstroemerias are still little accepted. In general, the varieties and cultivars of the company Konst Alstroemeria dominate the national consumption. The seedlings of these flowers are imported in vitro, directly from the Netherlands, and floral production in Brazil is governed by contracts established between producers and breeders, in which the amounts to be paid as annual royalties per plant are fixed. It is considered that the control of the production has been very successful, not being verified illegal propagation relevant (TOMBOLATO et al., 2010; 2013).

Commercial production of alstroemerias in Brazil is strongly concentrated in the State of São Paulo (90\%), followed by Minas Gerais (8\%), Rio Grande do Sul, Rio de Janeiro and Paraná (2\%). Currently, there are 134 cultivars and protected 52 .

\section{Zantedeschia}

The traditional white variety of the species is widespread throughout much of the country, being cultivated by small family farmers. It does not arouse the interest of the genetic industry, since its market shows decadent movement during the last decades, mainly because of its low post-harvest durability and high susceptibility to mechanical damages in the transport and handling of flowers in medium and long distances routes.

The colorful varieties, the most recent introduction in Brazil, have been having a great impact on the market, thus attracting attention from breeders. However, the restrictions on the broader development of this market are due in particular to high production costs, since cultivars are demanding in protected cultivation, with water and temperature control. Thus, higher flower prices on the market inhibit the expansion of consumption.

The cultivars preferred for cultivation as bottled flowers are in $95 \%$ of the cases the colored ones, being that the white ones are only $5 \%$ of the market. In the case of cut flowers, the Brazilian market preferences are: yellow $(40 \%)$, orange $(25 \%)$, pink $(25 \%)$ and other colors $(10 \%)$. The production is concentrated in the States of São Paulo, Minas Gerais and the mountain region of Espírito Santo.

\section{Hemerocallis}

The development of the Hemerocallis sp market in Brazil was due in particular to the introduction of North American cultivars for the landscaping market, which later became the basis for the program of genetic improvement of the species by the Agronomic Institute of Campinas (IAC). This project was established in partnership between the public institution and the private company Agrícola da Ilha Ltda., Established in the city of Joinville, in Santa Catarina. With an initial cycle of 12 years, the program also counted with the collaboration of the German improver, Ernest Stoberg. Currently, 60 different cultivars are in the company's catalog, with an annual commercial production of more than one million and three hundred thousand seedlings.

Fourteen cultivars of Hemerocallis sp and five cultivars of Hemerocallis hybrida were registered at the RNC, by the Agronomic Institute of Campinas (IAC). In turn, the the private company Agrícola da Ilha Ltda. has three other records, respectively for Hemerocallis middendorffii var. Esculenta (Koidz) Ohw. Hemerocallis aurantiaca Baker, Hemerocallis thunbergii Barr. Hemerocallis flava var. Minor (Mill) M. Hotta.

\section{Colorful sunflower}

This is one of the ornamental products developed by the Empresa Brasileira de Pesquisa Agropecuária - Embrapa (Brazilian Agricultural Research Corporation), with seeds commercially released to the country's florists since the second half of 2002. They were developed through the Embrapa Ornamental Sunflower Program - initiated in Londrina (PR), in 1996, nine different tonalities for the flowers of the species: wine, rose, light pink, dark pink, light yellow center lemon, dark center yellow lemon, mixed, rust and ray Sun. Some cultivars produce only one flower per plant, smaller in size than the one traditionally used for the production of oleaginous grains, and are the most suitable for the cut flower segment, with post-harvest duration of ten days. Other cultivars produce more than one flower per plant and are best suited for garden composition, with flowers that last for up to 25 days. 
This type of ornamental product was already known and appreciated in the USA and Europe, but was not cultivated in Brazil, since the international cultivars were not adapted to the environmental conditions of the Country.

\section{Ornamental pineapple}

Brazil is considered the largest of the centers of origin and diversity and genetic variability of the genus Ananas belongs to the order Bromeliales, family Bromeliaceae. Embrapa Mandioca e Fruticultura Tropical together with EMBRAPA Genetic Resources and Biotechnology develops projects for the collection, exchange and conservation of pineapple germplasm, through which it was possible to establish an Active Germplasm Bank (BAG), which currently has 670 accesses (SOUZA et al., 2007), of which 31 ornamental hybrids have already been obtained, three in the validation phase and market launch.

Only three varieties of ornamental interest are currently commercially grown: Ananas comosus var. erectifolius, $A$. comosus var. bracteatus and A. comosus var. ananassoides, being the first one responsible for $75 \%$ of the total produced (CARVALHO et al., 2014). This picture has led to the search for new varieties, since the market is characterized by the dynamics of the permanent search for novelties.

Brazil, the only country with commercial crops, has the opportunity to increase its participation in the markets where it already operates and seek new alternatives for the commercialization of this product. Concentrated in the Northeast region, mainly in the states of Ceará and Rio Grande do Norte, the plantations are already focused on meeting the requirements of the external market.

\section{Ornamental passion fruit}

There are 130 species of passion fruit in Brazil. The germplasm bank of Embrapa Cerrados, considered the largest worldwide collection of passiflora, has 150 accesses of 40 species. The ornamental varieties of this fruit species were developed by EMBRAPA Cerrados (Planaltina-DF) and EMBRAPA Transferência de Tecnologia (Brasília-DF) as a result of crosses of two different wild passion fruit species. The BRS Estrela do Cerrado, BRS Rubiflora and BRS Roseflora ornamental hybrids hit the market in the second half of 2008 .

\section{CONCLUSIONS}

The relatively recent implementation of the Law of Protection of Cultivars in Brazil has contributed to the country's alignment with the main trends of the commercial floriculture industry, making the national domestic market more attractive to the launches and innovations in genetic research by the main international breeders. However, there are limitations in the application of the legislation in relation to the ornamental sector, since it was essentially designed for the protection of cultivars of large crops, for the protection of food security and for family farmers, as well as for the supervision of plantations And the marketing of crops on the domestic market have limited the effective and full realization of their potential benefits.
High financial costs for crop protection records, a short time between the introduction of the cultivar in the market and the maximum legal term for its protection, acceleration of the rapid decline of the life cycle of many species and small areas of production by cultivar are other difficulties encountered by breeders In the Brazilian market of flowers and ornamental plants and that have been discouraging, also, the development of the national ornamental genetics.

In this scenario, it is necessary and urgent to adapt the legislation to the specificity of the Brazilian flower industry, in order to favor the research and the permanent development of the floral genetic industry in an inclusive manner of Brazil in the market of novelties and launches, a factor that is essential for the continued growth of the domestic market and the national insertion in world trade.

It is suggested that further studies be conducted in Brazil to support the full consolidation and advantageous exploitation of intellectual property rights potentials, especially as regards the intensification of exploratory research of consumers' desires, needs and expectations regarding new varieties and cultivars and on identifying characteristics and limits of the Brazilian market of flowers and ornamental plants in relation to new species and commercial cultivars.

\section{REFERENCES}

BRASIL. Ministério da Agricultura, Pecuária e Abastecimento. Serviço Nacional de Proteção de Cultivares (SNPC). Listagem das cultivares protegidas, 2017. Disponível em: http://extranet.agricultura.gov.br/php/snpc/ cultivarweb/cultivares_protegidas.php. Acesso em: $8 \mathrm{de}$ junho de 2017.

BRASIL. Ministério da Agricultura, Pecuária e Abastecimento. Serviço Nacional de Proteção de Cultivares (SNPC). Listagem das cultivares registradas, 2017. Disponível em: <http://extranet.agricultura.gov.br/php/ snpc/cultivarweb/cultivares_protegidas.php $>$. Acesso em: 8 de junho de 2017.

BRASIL. Presidência da República. Lei de Proteção de Cultivares. Lei n. 9.456, de 25 de abril de 1997.

BRASIL. Presidência da República. Lei de Sementes e Mudas. Lei n. 10.711, de 5 de agosto de 2003.

BROEK, L.V.D.; VELDT, T.V.; CARVALHO, T.B. Impacto dos royalties na comercialização nacional de flores: um estudo multi-caso, Anais do $4^{\circ}$ Congresso da Sociedade Brasileira de Economia e Sociologia Rural, Fortaleza, 2006.

CARPI, V.A.F. Registro Nacional de Cultivares. II Workshop DFIA-ABCSEM, Campinas, julho de 2017.

CARVALHO, A.C.P.P.; SOUZA, F.V.D.; SOUZA, E.H. Produção de abacaxizeiro ornamental para flor de corte. Fortaleza: Embrapa Agroindústria Tropical, 2014. 
INFOAGRO. The gerber daisy growing. Disponível em: http://www.infoagro.com/flores/flores/gerbera.htm. Acesso em: 18 de março de 2017.

JUNQUEIRA, A.H.; PEETZ, M.S. Brazilian consumption of flowers and ornamental plants: habits, practices and trends. Ornamental Horticulture, v.23, n.2, p.178-184, 2017.

JUNQUEIRA, A.H.; PEETZ, M.S. Comercialização de antúrios no Brasil. In: CASTRO, A.C.R; TERAO, D.; CARVALHO, A.C.P.P.; LOGES, V. (Eds.). Antúrio. Brasília: Embrapa, 2012. p.147-163.

JUNQUEIRA, A.H.; PEETZ, M.S. Mercado interno para os produtos da floricultura brasileira: características, tendências e importância socioeconômica recente. Revista Brasileira de Horticultura Ornamental, v.14, n.1, p.37-52, 2008.

JUNQUEIRA, A.H.; PEETZ, M.S. Tecnologia no cultivo de flores no Brasil, Anuário da Agricultura Brasileira - Agrianual 2016, São Paulo, Informa Economics FNP, p.282-284, 2016.

PAIVA, P.D.; LANDGRAF, P.R.C.; JUNQUEIRA. A.H.; PEETZ, M.S.; BOLDRIN, K.V.F. Floricultura no Brasil, Revista da Associação Portuguesa de Horticultura, n.121, p.30-33, 2016.

SÁ, C. D. Propriedade intelectual na cadeia de flores e plantas ornamentais: uma análise da legislação brasileira de proteção de cultivares. Dissertação (Mestrado). Faculdade de Economia, Administração e Contabilidade, Universidade de São Paulo, 2010.

SÁ, C.D.; SAES, M.S.M. Propriedade intelectual na cadeia de flores e plantas ornamentais: uma análise da legislação brasileira de proteção de cultivares. Revista Brasileira de Inovação, v.14, n.1, p.49-76, 2015.
SOUZA, F.V.D.; CABRAL, J.R.S.; SOUZA, E.H.; SANTOS, O.S.N.; SANTOS-SEREJO, J.A.; FERREIRA, F.R. Caracterização morfológica de abacaxizeiros ornamentais, Magistra, v.19, n.1, p.319-325, 2007.

TOMBOLATO, A.F.C.; UZZO, R.P.; JUNQUEIRA, A.H.; PEETZ, M.S; STANCATO. Geophyte research and production in Brazil. In: KAMENETSKY, R.; OKUBO, H. (Eds.). Ornamental geophytes: from basic science to sustainable production. Boca Raton: CRC Press, 2013. p.435-448.

TOMBOLATO, A.F.C.; UZZO, R.P.; JUNQUEIRA, A.H.; PEETZ, M.S; STANCATO, G.C.; ALEXANDRE, M.A.V. Bulbosas ornamentais no Brasil. Revista Brasileira de Horticultura Ornamental, v.16, n.2, p.127-138, 2010.

UNION POUR LA PROTÉCCION DES OBTENCIONES VEGETALES (UPOV). UPOV Report on teh impact of plant variety proteccion. Genebra, 2005 (Document $n$. $353(\mathrm{E})$.

VAN ROOIJEN, S.R.P.S. Proteção de cultivares no Brasil e seu impacto para o setor de flores e plantas ornamentais. Associação Brasileira de Proteção de Cultivares de Flores e Plantas Ornamentais, Atibaia, SP, 2006.

WILLIAMSON, O.E. Transaction Cost Economics and Organization Theory. In: SMELSER, N.J.; SWEDBERG, R. (editors). The handbook of economic sociology. Princeton: Princeton University Press, 1994. 